\title{
Synthesis and Spectroscopic Analysis of Schiff Bases of Imesatin and Isatin Derivatives
}

\section{${ }^{1,2^{*}}$ OLUBUNMI S. OGUNTOYE; ${ }^{1}$ ABDULMUMEEN A. HAMID; ${ }^{1}$ GABRIEL S. ILOKA; ${ }^{2}$ SUNDAY O. BODEDE; ${ }^{1}$ SAMSON O. OWALUDE; ${ }^{1}$ ADEDIBU C. TELLA}

\author{
${ }^{1}$ Department of Chemistry, Bioorganic Chemistry Research Group, Faculty of Physical Sciences, University of Ilorin, P.M.B 1515,Ilorin, Kwara State, \\ Nigeria. \\ ${ }^{2}$ Natural Products Research Group, School of Chemistry and Physics, University of KwaZulu- \\ Natal, Private Bag X54001, Durban, 4000, South Africa
}

\begin{abstract}
A series of new Schiff bases of Imesatin and Isatin derivatives which have been previously prepared from the reaction of Hydrazine monohydrate, $p$-phenylenediamine and 4,4diaminodiphenylmethane with Isatin were reported. The compounds were characterized by elemental analyses, UV-visible, Infrared and Nuclear Magnetic Resonance $\left({ }^{1} \mathrm{H}\right.$ NMR and ${ }^{13} \mathrm{C}$ NMR) spectroscopic analyses. The synthesized Schiff bases were obtained in moderate to excellent yields between $55.3-89.3 \%$. Infrared spectra of all synthesized compounds contain the characteristic azomethine linkage $(-\mathrm{CH}=\mathrm{N})$ between $1580-1630 \mathrm{~cm}^{-1}$ and the $\mathrm{N}-\mathrm{H}$ of the Isatin ring signals between $\delta 8.32-10.68 \mathrm{ppm}$ in their ${ }^{1} \mathrm{H}$ NMR spectra. The present work affords reaction pathway that is efficient and operational simplicity for the synthesis of Schiff bases derivatives. @JASEM

http://dx.doi.org/10.4314/jasem.v20i3.20
\end{abstract}

Keywords: Schiff bases, isatin, imesatin, spectroscopic analysis, biological activity

Isatin (1H-indole-2, 3-Dione) was first synthesized by Erdman, 1840 and established by Laurent, 1841 as a product from the oxidation of indigo by nitric and chromic acids. The synthetic versatility of Isatin has led to the wide applications of this compound in organic synthesis with medical and pharmacological properties of its derivatives extensively studied (Da Silva et al., 2001). A number of Schiff bases derived from Isatin and Imesatin derivatives have been reported with various biological properties such as, antimicrobial (Bari et al., 2008; Kumar et al., 2010; Chaluvaraju and Zaranappa, 2011), Central nervous system (CNS) depressant (Pandeya and Raja, 2002; Singh et al.,2004; Smitha et al., 2008), anti-HIV (Teitz et al., 1994; Pandeya et al., 1998; Pandeya et al., 1999), anti-inflammatory (Khan et al., 2006; Babu et al., 2010; Panneerselvam et al., 2010), analgesic (Reddy, 2008) and as anticancer agents (Vine $e t$ al., 2007; Aboul-Fadi et al., 2012). These class of compounds have also been variously applied in a number of other applications such as, identification, detection and determination of aldehydes or ketones; purification of carbonyl or amino compounds and for protection of these groups during complex or sensitive reactions (Raman et al., 2007). In organic synthesis, Schiff base reactions are useful in making carbon-nitrogen bonds and serve as important intermediate in a number of enzymatic reactions involving interaction of an enzyme with an amino or a carbonyl group of the substrate (Daniel et al., 2003).

The condensation of a primary amine in an enzyme, usually that of a lysine residue, with a carbonyl group of the substrate to form Schiff base or Imesatin is one of the most important types of catalytic mechanism in biochemical processes (Kaura and Kaura, 2012; Eissa, 2015).

In the light of different applications of Schiff bases derived from Isatin, we hereby report the synthesis of new Schiff bases derived from Isatin and Imesatin derivatives, investigation of biological and catalytic activities of these compounds is a subject of an ongoing research in our laboratory.

\section{MATERIALS AND METHOD}

All the chemicals used were analytical grade obtained from Sigma-Aldrich via Capital lab supplies, South Africa. All the solvents were redistilled and dried according to standard procedures (Glikbery and Marcus, 1985; Wheet, 2011).

Melting points were determined in open capillary tube and are uncorrected using Gallen Kamp scientific melting point apparatus GKI05. The progress of the reaction were routinely checked by Thin-layer chromatography on Merck pre-coated Silica gel $60 \mathrm{~F}_{254}$ plates, $0.25 \mathrm{~mm}$, Germany using solvent system of Benzene/ethanol (9:1), developed and visualized under UV lamp at 254 and 366 nm. UV-Visible spectrometric data of the synthesized compounds were recorded on Beckman Coulter DU 730 UV-Visible Spectrophotometer. Infrared spectra were recorded on a Perkin Elmer Spectrum 100 FT-IR spectrometer with universal attenuated total reflectance 
(ATM) sampling accessory. ${ }^{1} \mathrm{H}$ and ${ }^{13} \mathrm{C}$ NMR spectra were recorded at $298 \mathrm{~K}$ with $5.0-10.0 \mathrm{mg}$ of samples dissolved in $0.75 \mathrm{ml}\left(\mathrm{CD}_{3}\right)_{2} \mathrm{SO}$ and $\mathrm{CDCl}_{3}$ in $5.0 \mathrm{~mm}$ NMR tube using 400.22 $\mathrm{MHz}$ and $100.63 \mathrm{MHz} 9.4 \mathrm{~T}$ Bruker, Germany NMR spectrometers respectively. Gradient heteronuclear single quantum coherence (HSQC), gradient heteronuclear multiple-bond correlation (HMBC) and nuclear over hauser effect spectroscopy (NOESY) spectra were all recorded using $376.58 \mathrm{MHz}$ on the same NMR spectrometer. The digital digitizer resolution was set at 22 for both ${ }^{1} \mathrm{H}$ and ${ }^{13} \mathrm{C}$ NMR experiments. Chemical shifts $(\delta)$ were recorded against an internal standard, tetramethylsilane (TMS) for ${ }^{1} \mathrm{H}$ and ${ }^{13} \mathrm{C}$ NMR. Elemental analyses were carried out on a PerkinElmer CHN Analyser 2400 Series II.

Preparation of Derivatives: Synthesis of Schiff bases of Imesatin and Isatin: The compounds were prepared by a slight modification of literature procedures (Ibrahim et al., 2006; Chaluvaraju and Zaranappa, 2011; Kaura and Kaura, 2012). Isatin (1.47 g, $1 \mathrm{mmol})$, was separately added to equimolar quantity of $p$-Phenylenediamine (1.08 $\mathrm{g}, 1 \mathrm{mmol})$, Hydrazine monohydrate $(0.51 \mathrm{~g}, 1 \mathrm{mmol})$ and $4,4^{\prime}$-Diaminodiphenylmethane $(0.20 \mathrm{~g}, 1 \mathrm{mmol})$ in $30 \mathrm{ml}$ of methanol containing $5 \mathrm{ml}$ of glacial acetic acid inside a $100 \mathrm{ml}$ round bottomed flask. The reaction mixture was heated to reflux for $2 \mathrm{~h}$ at the refluxing temperature. The solvent was then distilled off to obtain precipitates which were cooled, filtered and washed with distilled water $(2 \mathrm{x}$ $10 \mathrm{ml})$. Recrystallization from ethanol afforded the pure Imesatin derivatives.

Equimolar quantity of purified Imesatin derivatives and various substituted aromatic aldehydes were dissolved in $30 \mathrm{ml}$ ethanol and the mixtures heated to reflux for $8 \mathrm{~h}$. The resulting solution was cooled and the solvent was removed on a Buchi R-215 rotary evaporator. The solid residue was washed with distilled water to obtain the crude product. The crude product was purified by recrystallization in ethanol to afford Schiff base of Isatin derivatives.

\section{RESULTS AND DISCUSSION}

Spectroscopic and analytical data of synthesized Schiff base of Imesatin and Isatin derivatives

3-hydrazono-indoline-2-one: Yield (\%): 77.9; m.pt. $\left({ }^{\circ} \mathbf{C}\right): 226-228$; UV $\lambda_{\max }(\mathrm{nm}): 238\left(\pi \rightarrow \pi^{*}\right), 303\left(\mathrm{n} \rightarrow \sigma^{*}\right)$; IR $v_{\max }\left(\mathrm{cm}^{-1}\right): 3350(\mathrm{~N}-\mathrm{H}), 3143$ (N-H Isatin), 1655 $(\mathrm{C}=\mathrm{O}), 1583(\mathrm{C}=\mathrm{N}) ;{ }^{1} \mathbf{H}$ NMR (DMSO-d $\left.{ }_{6}\right): \delta \mathrm{ppm} 10.68$ $(\mathrm{s}, 1 \mathrm{H},-\mathrm{N}-\mathrm{H}), 10.55\left(\mathrm{~d}, \mathrm{~J}=14.2 \mathrm{~Hz}, 1 \mathrm{H},-\mathrm{NH}_{2}\right), 9.55(\mathrm{~d}$, $\left.\mathrm{J}=14.2 \mathrm{~Hz}, 1 \mathrm{H},-\mathrm{NH}_{2}\right), 6.85-7.37$ (m, 4H, H-4, H-5, H-6, $\mathrm{H}-7, \mathrm{Ar}-\mathrm{H}) ;{ }^{13} \mathbf{C}$ NMR (DMSO-d $\mathbf{d}_{\mathbf{6}}$ ): $\delta$ ppm $110-138$ (Ar-C), $164(\mathrm{C}=\mathrm{N}), 162(\mathrm{C}=\mathrm{O})$; Anal. Calcd. for $\mathrm{C}_{8} \mathrm{H}_{7} \mathrm{~N}_{3} \mathrm{O} ; \mathrm{C}, 59.62 ; \mathrm{H}, 4.38 ; \mathrm{N}, 26.07 ; \mathrm{O}, 9.93$; Found $\mathrm{C}$ 59.68; H, 4.36; N, 26.01; O, 9.95 . 3-(2',4'-dimethoxybenzylidenehydrazono)indoline-2one: Yield (\%): 69.4; m.pt. $\left({ }^{\circ} \mathbf{C}\right): 203-204 ; \mathbf{U V} \lambda_{\max }(\mathrm{nm})$ : $210\left(\pi \rightarrow \pi^{*}\right), 300\left(\mathrm{n} \rightarrow \sigma^{*}\right)$; IR $v_{\max }\left(\mathrm{cm}^{-1}\right): 3141(\mathrm{~N}-\mathrm{H}$ Isatin), $3070(\mathrm{Ar}, \mathrm{H}), 1709(\mathrm{C}=\mathrm{O}), 1665(\mathrm{C}=\mathrm{C}), 1577$ $(\mathrm{C}=\mathrm{N}), 1268(\mathrm{C}-\mathrm{O}-\mathrm{C}) ;{ }^{1} \mathbf{H}$ NMR $\left(\mathbf{C D C l}_{3}\right): \delta \mathrm{ppm} 8.92(\mathrm{~s}$, $1 \mathrm{H}, \mathrm{N}-\mathrm{H}), 8.27$ (d, J=7.5 Hz, 1H, -N=CH-), 6.46-7.87 (m, 7H, H-4, H-5, H-6, H-7, H-2', H-3', H-5', Ar-H), 3.8 (s, $\left.6 \mathrm{H}, \mathrm{OCH}_{3}\right) ;{ }^{13} \mathbf{C} \mathbf{N M R}\left(\mathbf{C D C l}_{3}\right): \delta$ ppm $55\left(-\mathrm{OCH}_{3}\right), 97-$ $98(\mathrm{C}-\mathrm{O}), 110-164(\mathrm{Ar}-\mathrm{C}), 166(\mathrm{C}=\mathrm{N}), 163(\mathrm{C}=\mathrm{O})$; Anal. Calcd.for $\mathrm{C}_{17} \mathrm{H}_{15} \mathrm{~N}_{3} \mathrm{O}_{3} ; \mathrm{C}, 66.01 ; \mathrm{H}, 4.89 ; \mathrm{N}, 13.58$; O, 15.52; Found C 66.08; H, 4.65; N, 13.12; O, 16.15 .

\section{3-(2'-hydroxy-4'-methoxybenzylidenehydrazono)} indoline-2-one: Yield (\%): 84.7; m.pt. $\left({ }^{\circ} \mathbf{C}\right): 176-177$; UV $\lambda_{\max }(\mathrm{nm}): 246\left(\pi \rightarrow \pi^{*}\right), 470\left(\mathrm{n} \rightarrow \sigma^{*}\right) ; \mathbf{I R} v_{\max }\left(\mathrm{cm}^{-1}\right)$ : 3350 (O-H), 3150 (N-H Isatin), $1743(\mathrm{C}=\mathrm{O}), 1685(\mathrm{C}=\mathrm{C})$, $1592(\mathrm{C}=\mathrm{N}), 1286(\mathrm{C}-\mathrm{O}-\mathrm{C}) ;{ }^{1} \mathbf{H}$ NMR (DMSO-d $\left.)_{6}\right): \delta$ ppm 9.98 (s, 1H, N-H), 8.03 (d, J=7.32 Hz, 1H, -N=CH-), 6.46-6.64 (m, 3H, H-2', H-3', H-5', Ar-H), 6.85-7.62 (m, $7 \mathrm{H}, \mathrm{H}-4, \mathrm{H}-5, \mathrm{H}-6, \mathrm{H}-7, \mathrm{Ar}-\mathrm{H}), 3.81$ (t, J=4.5 Hz, 3H); ${ }^{13}$ C NMR (DMSO-d $\left.)_{6}\right): \delta$ ppm $55\left(-\mathrm{OCH}_{3}\right), 110-164$ (Ar-C), $165(\mathrm{C}=\mathrm{N}), \quad 160 \quad(\mathrm{C}=\mathrm{O})$; Anal. Calcd.for $\mathrm{C}_{16} \mathrm{H}_{13} \mathrm{~N}_{3} \mathrm{O}_{3} ; \mathrm{C}, 65.08 ; \mathrm{H}, 4.44 ; \mathrm{N}, 14.23 ; \mathrm{O}, 16.25$; Found C $65.12 ; \mathrm{H}, 4.23 ; \mathrm{N}, 14.12 ; \mathrm{O}, 16.53$

3-((4'-(4"'-aminobenzyl) phenyl)imino)indoline-2-one: Yield (\%): 81.6; m.pt. $\left({ }^{\circ} \mathbf{C}\right): 321-322 ;$ UV $\lambda_{\max }(\mathrm{nm}): 203$ $\left(\pi \rightarrow \pi^{*}\right), 309\left(\mathrm{n} \rightarrow \sigma^{*}\right) ; \quad$ IR $v_{\max }\left(\mathrm{cm}^{-1}\right): 3231(\mathrm{~N}-\mathrm{H}), 1739$ $(\mathrm{C}=\mathrm{O}), 1652(\mathrm{C}=\mathrm{C}), 1609(\mathrm{C}=\mathrm{N}) ;{ }^{1} \mathbf{H}$ NMR (DMSO-d $\left.)_{6}\right)$ : $\delta$ ppm $9.89\left(\mathrm{~d}, \mathrm{~J}=7.8 \mathrm{~Hz}, 2 \mathrm{H},-\mathrm{NH}_{2}\right), 6.42-7.41(\mathrm{~m}$, $12 \mathrm{H}, \quad \mathrm{Ar}-\mathrm{H}), 4.03$ ( s, 2H, Ar- $\left.\mathrm{CH}_{2}-\mathrm{Ar}\right) ;{ }^{13} \mathbf{C}$ NMR $\left(\mathbf{C D C l}_{3}\right): \delta$ ppm $40\left(\mathrm{CH}_{2}\right), 101-158(\mathrm{Ar}-\mathrm{C}), 163(\mathrm{C}=\mathrm{N})$, $161(\mathrm{C}=\mathrm{O})$; Anal. Calcd.for $\mathrm{C}_{21} \mathrm{H}_{17} \mathrm{~N}_{3} \mathrm{O}$; C, 77.04; $\mathrm{H}$, $5.23 ; \mathrm{N}, 12.84 ; \mathrm{O}, 4.89$; Found $\mathrm{C} 77.08 ; \mathrm{H}, 5.23 ; \mathrm{N}$, $12.75 ; \mathrm{O}, 4.94$

3-((4-4'-((2', 4''-dimethoxybenzylideneamino) benzyl) phenyl)imino)indoline-2-one: Yield (\%): 65.4; m.pt. $\left({ }^{\circ} \mathbf{C}\right): 351-352$; UV $\lambda_{\max }(\mathrm{nm}): 218\left(\pi \rightarrow \pi^{*}\right), 335\left(\mathrm{n} \rightarrow \sigma^{*}\right)$; IR $v_{\max }\left(\mathrm{cm}^{-1}\right): 3181(\mathrm{~N}-\mathrm{H}), 1738(\mathrm{C}=\mathrm{O}), 1653(\mathrm{C}=\mathrm{C})$, $1607(\mathrm{C}=\mathrm{N}), 1287(\mathrm{C}-\mathrm{O}-\mathrm{C}) ;{ }^{1} \mathbf{H}-\mathbf{N M R}\left(\mathbf{C D C l}_{3}\right): \delta \mathrm{ppm}$ 10.27 (s, 1H, -N-H), 7.79 (d, J=8.7 Hz, 1H, -N=CH), 6.42 - $7.24(\mathrm{~m}, 15 \mathrm{H}, \mathrm{Ar}-\mathrm{H}), 3.88\left(\mathrm{~s}, 3 \mathrm{H},-\mathrm{OCH}_{3}\right), 3.86(\mathrm{~s}, 3 \mathrm{H},-$ $\left.\mathrm{OCH}_{3}\right) ;{ }^{13} \mathbf{C}$ NMR $\left(\mathbf{C D C l}_{3}\right): \delta \mathrm{ppm} 40\left(\mathrm{CH}_{2}\right), 56\left(\mathrm{OCH}_{3}\right)$, 101 - 160 (Ar-C), $163(\mathrm{C}=\mathrm{N}), 161 \quad(\mathrm{C}=\mathrm{O})$; Anal. Calcd.for $\mathrm{C}_{30} \mathrm{H}_{25} \mathrm{~N}_{3} \mathrm{O}_{3} ; \mathrm{C}, 75.77 ; \mathrm{H}, 5.30 ; \mathrm{N}, 8.84 ; \mathrm{O}$, 10.09; Found C 75.54; H, 5.28; N, 8.56; O, 10.62

3-((4-4'-((2',-hydroxy-4''-methoxybenzylideneamino) benzyl) phenyl)imino)indoline-2-one: Yield (\%): 71.5; m.pt. $\left({ }^{\circ} \mathbf{C}\right): 324-325$; UV $\lambda_{\max }(\mathrm{nm}): 232\left(\pi \rightarrow \pi^{*}\right), 315$ $\left(\mathrm{n} \rightarrow \sigma^{*}\right) ; \mathbf{I R} v_{\max }\left(\mathrm{cm}^{-1}\right): 3190(\mathrm{~N}-\mathrm{H}), 1739(\mathrm{C}=\mathrm{O}), 1609$ $(\mathrm{C}=\mathrm{N}), 1289(\mathrm{C}-\mathrm{O}-\mathrm{C}) ;{ }^{1} \mathbf{H}$ NMR $\left(\mathbf{C D C l}_{\mathbf{3}}\right): \delta \mathrm{ppm} 8.53(\mathrm{~s}$, $1 \mathrm{H},-\mathrm{N}=\mathrm{CH}), 6.49-7.29(\mathrm{~m}, 15 \mathrm{H}, \mathrm{Ar}-\mathrm{Hs}), 4.04(\mathrm{~s}, 2 \mathrm{H}$, $\left.\mathrm{Ar}-\mathrm{CH}_{2}-\mathrm{Ar}\right) ;{ }^{13} \mathbf{C}$ NMR $\left(\mathbf{C D C l}_{3}\right): \delta$ ppm $40\left(\mathrm{CH}_{2}\right), 55$ $\left(\mathrm{OCH}_{3}\right), 101-159(\mathrm{Ar}-\mathrm{C}), 163(\mathrm{C}=\mathrm{N}), 161(\mathrm{C}=\mathrm{O})$; Anal. 
Calcd.for $\mathrm{C}_{29} \mathrm{H}_{23} \mathrm{~N}_{3} \mathrm{O}_{3} ;$ C, 75.47; H, 5.02; N, 9.10; O, 10.40; Found C 75.50; H, 4.98; N, 9.00; O, 10.52

3-(4'-aminophenylimino) indoline-2-one: Yield (\%): 89.3; m.pt. $\left({ }^{\circ} \mathbf{C}\right): 349-350$; UV $\lambda_{\max }(\mathrm{nm}): 238\left(\pi \rightarrow \pi^{*}\right)$, $303\left(\mathrm{n} \rightarrow \sigma^{*}\right) ; \mathbf{I R} v_{\max }\left(\mathrm{cm}^{-1}\right): 3085(\mathrm{Ar}-\mathrm{H}), 1724(\mathrm{C}=\mathrm{O})$, 1650 $(\mathrm{C}=\mathrm{C}), 1609(\mathrm{C}=\mathrm{N}) ;{ }^{1} \mathbf{H}$ NMR (DMSO-d $\left.{ }_{6}\right): \delta \mathrm{ppm}$ 8.32 (s, $1 \mathrm{H},-\mathrm{N}-\mathrm{H}), 6.63-7.61(\mathrm{~m}, 8 \mathrm{H}, \mathrm{Ar}-\mathrm{H}) ;{ }^{13} \mathbf{C}$ NMR $\left.(\text { DMSO-d })_{6}\right): \delta$ ppm $111-155(\mathrm{Ar}-\mathrm{C}), 163(\mathrm{C}=\mathrm{N}), 158$ $(\mathrm{C}=\mathrm{O})$; Anal. Calcd.for $\mathrm{C}_{14} \mathrm{H}_{11} \mathrm{~N}_{3} \mathrm{O} ; \mathrm{C}, 70.87 ; \mathrm{H}, 4.67 ; \mathrm{N}$, 17.71; O, 6.74; Found C 70.88; H, 4.56; N, 17.81; O, 6.75 .

\section{3-(4'-(2',4'-dimethoxybenzylideneamino)}

phenylimino) indoline-2-one: Yield (\%): 57.4; m.pt. $\left({ }^{\circ} \mathbf{C}\right): \quad 343-344 ; \quad$ UV $\quad \lambda_{\max }(\mathrm{nm}): \quad 227 \quad\left(\pi \rightarrow \pi^{*}\right), \quad 328$ $\left(\mathrm{n} \rightarrow \sigma^{*}\right) ; \mathbf{I R} v_{\max }\left(\mathrm{cm}^{-1}\right): 3148(\mathrm{~N}-\mathrm{H}), 3085(\mathrm{Ar}-\mathrm{H}), 1721$ $(\mathrm{C}=\mathrm{O}), 1651 \quad(\mathrm{C}=\mathrm{C}), 1608(\mathrm{C}=\mathrm{N}) 1290 \quad(\mathrm{C}-\mathrm{O}-\mathrm{C}) ;{ }^{1} \mathbf{H}$
NMR (DMSO-d (D) $^{-} \delta$ ppm $8.77(\mathrm{~s}, 1 \mathrm{H},-\mathrm{N}-\mathrm{H}), 7.97$ (d, $\mathrm{J}=8.3 \mathrm{~Hz}, 1 \mathrm{H},-\mathrm{N}=\mathrm{CH}), 6.67-7.62(\mathrm{~m}, 11 \mathrm{H}, \mathrm{Ar}-\mathrm{H}), 3.89$ (s, $\left.3 \mathrm{H}, \mathrm{OCH}_{3}\right), 3.85\left(\mathrm{~s}, 3 \mathrm{H}, \mathrm{OCH}_{3}\right) ;{ }^{13} \mathbf{C}$ NMR (DMSO$\left.\mathbf{d}_{\mathbf{6}}\right): \delta \mathrm{ppm} 55\left(\mathrm{OCH}_{3}\right), 111-150(\mathrm{Ar}-\mathrm{C}), 158(\mathrm{C}=\mathrm{N}), 158$ $(\mathrm{C}=\mathrm{O})$; Anal. Calcd.for $\mathrm{C}_{23} \mathrm{H}_{19} \mathrm{~N}_{3} \mathrm{O}_{3} ; \mathrm{C}, 71.68 ; \mathrm{H}, 4.97 ; \mathrm{N}$, 10.90; O, 12.45; Found C 71.56; H, 4.85; N, 10.86; O, 12.73 .

\section{3-(4'-(2'-hydroxy-4''-methoxybenzylideneamino)} phenylimino) indoline-2-one: Yield (\%): 55.3; m.pt. $\left({ }^{\circ} \mathbf{C}\right): 321-322 ; \mathbf{U V} \lambda_{\max }(\mathrm{nm}): 212\left(\pi \rightarrow \pi^{*}\right), 306\left(\mathrm{n} \rightarrow \sigma^{*}\right)$; IR $v_{\max }\left(\mathrm{cm}^{-1}\right): 1725(\mathrm{C}=\mathrm{O}), 1594(\mathrm{C}=\mathrm{C}), 1569(\mathrm{C}=\mathrm{N})$, 1289 (C-O-C); ${ }^{1} \mathbf{H}$ NMR (DMSO-d ${ }_{6}$ ): $\delta$ ppm 8.91 (s, $1 \mathrm{H}$, $-\mathrm{N}-\mathrm{H}), 8.74(\mathrm{~s}, 1 \mathrm{H},-\mathrm{N}=\mathrm{CH}), 6.48-7.62(\mathrm{~m}, 11 \mathrm{H}, \mathrm{Ar}-\mathrm{H})$, $3.79\left(\mathrm{t}, \mathrm{J}=2.4 \mathrm{~Hz}, 3 \mathrm{H}, \mathrm{OCH}_{3}\right) ;{ }^{13} \mathbf{C}$ NMR (DMSO): $\delta \mathrm{ppm}$ $56\left(\mathrm{OCH}_{3}\right), 115-160(\mathrm{Ar}-\mathrm{C}), 163(\mathrm{C}=\mathrm{N}), 158(\mathrm{C}=\mathrm{O})$; Anal. Calcd.for $\mathrm{C}_{22} \mathrm{H}_{17} \mathrm{~N}_{3} \mathrm{O}_{3} ; \mathrm{C}, 71.15 ; \mathrm{H}, 4.61 ; \mathrm{N}, 11.31$; O, 12.92; Found C 71.02; H, 4.50; N, 11.20; O, 13.28.

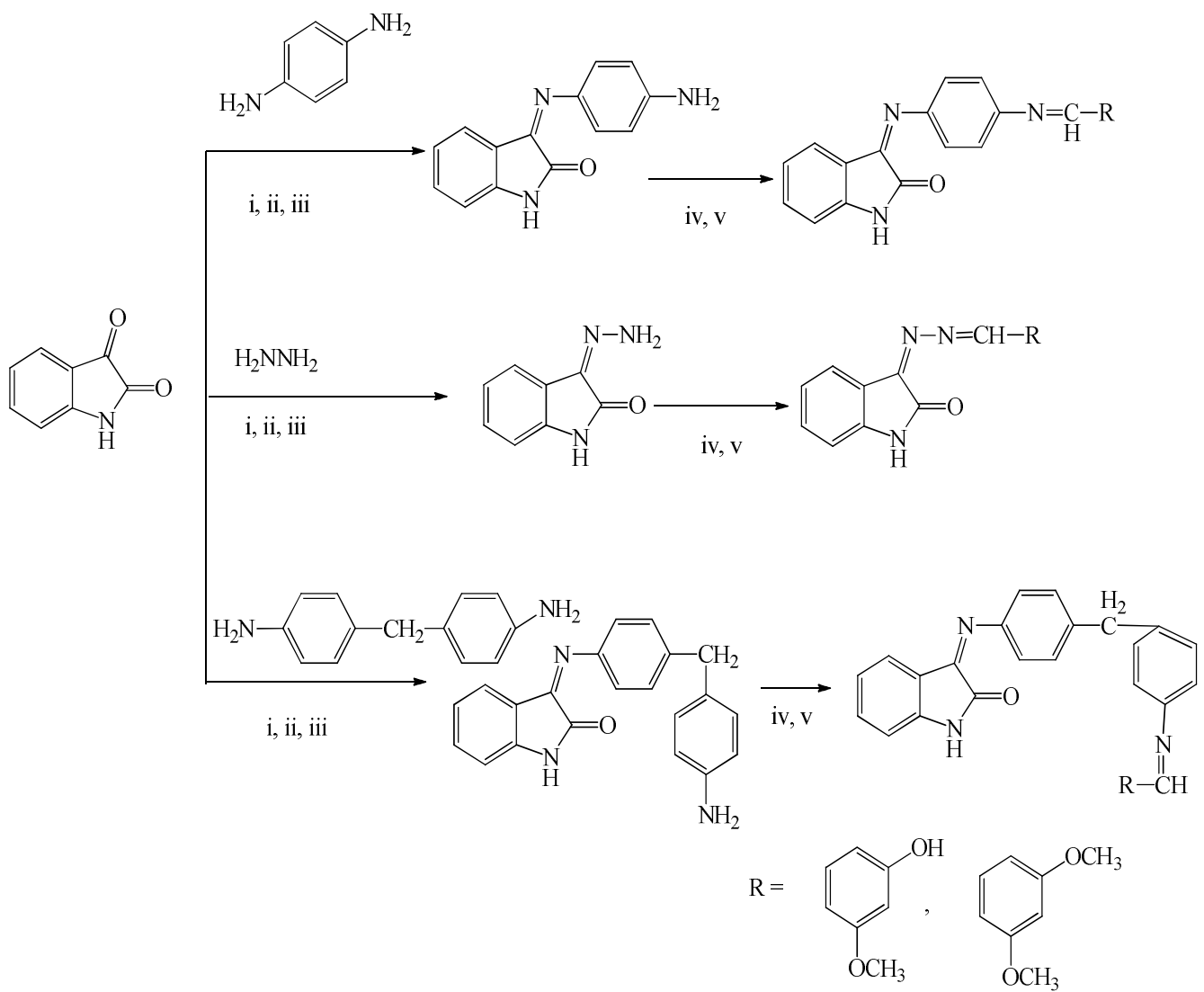

Scheme 1: Synthesis of the Schiff bases of Isatin and Imesatin derivatives (i) $\mathrm{CH}_{3} \mathrm{OH}$; (ii) $\mathrm{CH}_{3} \mathrm{COOH}$; (iii) reflux $2 \mathrm{~h}$ (iv) $\mathrm{CH}_{3} \mathrm{CH}_{2} \mathrm{OH}$, $\mathrm{RCHO}$ and reflux $8 \mathrm{~h}$.

The reaction pathways for the syntheses of the new compounds are shown in Scheme 1. The elemental analysis data and the sharp melting points obtained for these compounds are indication of the purity of the synthesized Schiff base derivatives. Most of the compounds were soluble in dimethylsulphoxide while the others were soluble in chloroform but insoluble in other common organic solvents. As shown in the experimental data, all the compounds were obtained in moderate to excellent yield and purity.

The IR spectra of all synthesized compounds show prominent strong bands in the range $1569-1609 \mathrm{~cm}^{-1}$ attributable to the presence of the characteristic 
azomethine $-\mathrm{CH}=\mathrm{N}$ linkage in all the compounds. This is a direct evidence of the formation of the desired Schiff bases. The presence of strong bands between $3141-3350$ $\mathrm{cm}^{-1}$ and weak bands in the region $1709-1743 \mathrm{~cm}^{-1}$ assignable to $\mathrm{N}-\mathrm{H}$ and $\mathrm{C}=\mathrm{O}$ vibrations of Imesatin and Isatin rings respectively (Manjusha et al., 2004). In all the Schiff base derivatives, bands due to $\mathrm{N}-\mathrm{H}$ and $\mathrm{C}=\mathrm{O}$ of Imesatin or Isatin ring which remain almost at similar positions, indicating their non-involvement in the bond formation. Proton magnetic resonance spectra of the Schiff base of Imesatin and Isatin derivatives were assigned using different chemical shifts $(\delta)$. Signals due to the $\mathrm{N}-\mathrm{H}$ group of the Isatin ring appears at $\delta 8.77-10.68$ and multiplets peaks observed for the aromatic ring protons between $\delta 6.42-7.87$. The characteristic $-\mathrm{N}=\mathrm{C}-$ $\mathrm{H}$ signal appears between $\delta 7.79-8.97$ in all the synthesized compounds and absence of the same signal in the Imesatin structures indicates the formation of Schiff base derivatives through their primary amino group (Manjusha et al., 2004; Aliasghar et al., 2007; Prakash et al., 2010; Eissa, 2015). The ${ }^{13} \mathrm{C}-\mathrm{NMR}$ results are consistent with the ${ }^{1} \mathrm{H}-\mathrm{NMR}$ results.

Conclusion: This research reports a series of Schiff base of Imesatin and Isatin derivatives synthesized by the reaction of hydrazine monohydrate, $p$-phenylenediamine and 4, 4'-diaminodiphenylmethane with Isatin and further condensation of the products (Imesatin) with different aromatic aldehydes. The synthesized derivatives are all coloured compounds, mostly soluble in dimethylsulphoxide. Physical characterization using spectroscopic techniques was employed in the elucidation of the structures of the synthesized derivatives. This class of compounds might have some important biological activity and can be effectively utilized as lead molecules for drug development. Further studies on this class of compounds are in progress for getting more information on their pharmacological and toxicological importance.

Acknowledgement: OSO wish to acknowledge the University Of KwaZulu Natal South Africa, for the award of a postdoctoral scholarship and the support given by University of Ilorin, Nigeria for leave to honour the fellowship.

\section{REFERENCES}

Aboul-Fadl, T; Awwad, AR; Mohammed, IA; Abdullah, A; Hatem, AA (2012) Schiff Bases of Indoline-2,3dione (Isatin) with Potential Anti-proliferative Activity, Chemistry Central Journal, 6:49.

Aliasghar, J; Dariush, K; Erik De, C; Chanaz, S; Jean, M (2007) Synthesis, Antibacterial, Antifungal and Antiviral Activity Evaluation of Some New bisSchiff Bases of Isatin and Their Derivatives, Molecules, 12:1720-1730.
Babu, GS; Ranjani, N; Rao, V (2010) Synthesis and Antiinflammatory Activity of Isatin Derivatives, Der Pharma Chemica. 2(3):196-204.

Bari, SB; Agrawal, AO; Patil, UK (2008) Synthesis and Pharmacological Evaluation of some Novel Isatin Derivatives for Antimicrobial Activity, Journal of Sciences, 19(3):217-221.

Chaluvaraju, KC; Zaranappa, R (2011) Synthesis and Microbiological Evaluation of some Isatin Derivatives for Antimicrobial Properties, Research Journal of Pharmaceutical, Biological and Chemical Sciences, 2(1):541.

Da Silva, JFM; Garden, SJ; Pinto, AC (2001) The Chemistry of Isatins: Review from 1975 to1999. J. Braz. Chem. Soc. 12(3):273-324.

Daniel, L; Purich, R; Donald, A (2003) The Enzyme Reference: A Comprehensive Guidebook to Enzyme Nomenclature, Reactions, and Methods. Elsevier Science, Academic Press, California (USA) pp. 45-50

Eissa, HH (2015) Synthesis, Characterization, Anticorrosion Activities and Antibacterial Activities of New Schiff Bases, BAOJ Chem. 1(2): 1-9.

Erdmann, OL (1840) Untersuchungen über den Indigo, Journal fürPraktischeChemie 19(1):321-362.

Glikberg, S and Marcus, Y (1985) Recommended Methods for the purification of Solvents and Tests for Impurities Methanol and Ethanol, Pure an Applied Chemistry, 57(6):855-864

Ibrahim, MN; Hamad, KJ; Al-joroshi, SH (2006) Synthesis and Characterization of some Schiff bases, Asian Journal of Chemistry, 18 (3): 2404-2406.

Khan, SA; Siddiqui, N; Imran, M; Haque, SW (2006) Synthesis and Biological Evaluation of some Novel Mannich Bases of Isatin, Journal of Pharmaceutical Research, 5(2):61-64.

Kaura, AK; Kaura, M (2012) Synthesis, Spectral and Comparative Antimicrobial Study of Schiff bases, International Journal of Chemical and Pharmaceutical Sciences, 3(4):24-29.

Kumar, V; Kukshal, A; Rathee, P (2010) Synthesis and Antimicrobial Activity of 5-substituted 1H-indole2,3-dione-3-N-(4'-substitutedphenyl) thiosemicarbazone, Res. J. Pharm. 1:98-103. 
Laurent, A (1841) Reseachessurl'indigo, Annales de Chimie et de Physique, 3(3):393-434.

Manjusha, V; Surendra, N; Pandeya, K; Singh, N; James, PS (2004) Anticonvulsant Activity of Schiff Bases of Isatin Derivatives, Acta Pharm. 54:49-56.

Pandeya, SN; Raja, AS (2002) Synthesis of Isatin semicarbazones as novel anti-convulsants role of hydrogen bonding, J. Pharma Phamaceut Sci, 5(3):266-271.

Pandeya, SN; Yogeeswari, P; Sriram, D; Nath, G (1998) Synthesis, characterization and anti convulsant activity of novel Schiff base of Isatin derivatives. Anticonvulsant activity of Schiff bases of Isatin derivatives, Boll Chim Farm, 137:321-324.

Pandeya, SN; Sriram, D; Nath, G (1999) Synthesis Antibacterial, Antifungal and Anti-HIV Activity of Schiff's and Mannich B bases of Isatin with N-[6Chlorobenzthiazole-2yl]thiosemicarbazide. Indian J. Pharm. Sci.16(6):358-361.

Panneerselvam, P; Kumar, NR; Murali, K (2010) Synthesis, Analgesic, Anti-inflammatory and Antimicrobial Activities of some Novel Schiff's Bases of 5-subsituted Isatin, Der Pharma Chemica, 2(1):28-37.

Prakash, CR; Raja, S; Saravanan, G (2010) Synthesis, Characterization and Anti-convulsant Activity of Novel Schiff Base of Isatin Derivatives, International Journal of Pharmacy and Pharmaceutical Sciences, 2(4):177-181.
Raman, N; Raja, JD and Sakthivel, A (2007) Synthesis, Spectral Characterization of Schiff base Transition Metal Complexes: DNA Cleavage and Antimicrobial Activity Studies. Journal of Chemical Science, 119(4): 303-310.

Reddy, RK (2008) Cobalt (II), Ni (II), Zn (II), CD (II), Hg (II) and $\mathrm{UO}_{2}$ (VI) complexes from

on Schiff base ligand, J. Chil. Chem. Soc. 53(4):16531657.

Singh, KN; Verma, M; Pandaye, SN (2004) Anticonvulsant activity of Schiff bases of Isatin derivatives, Acta Pharm, 54:49-56.

Smitha, S; Pandeya, SN; Stables, JP; Ganpathy, S (2008) Anticonvulsant and Sedative Hypnotic Activities of $\mathrm{N}$-acetyl/methyl Isatin Derivatives, Sci. Pharm. 76:621-636.

Teitz, Y; Ronen, D; Vansover, A; Stematsky, T (1994) Inhibition of Human Immuno Deficiency Virus by Nmethylisatin- $\beta 44^{`}: 4^{`}$-diallyisatin- $\beta-4$ : $4^{`}$ -

diallythiosemicarbazone. Antiviral Res, 24:305-314.

Vine, KL; Locke, JM; Ronson, M (2007) In vitro Cytotoxicity Evaluation of some Substituted Isatin Derivatives, Bioorg. Med. Chem. 15:931-938.

Wheet, R (2011) Organic Chemistry Laboratory Procedures $4^{\text {th }}$ Edition. Texas State Technical College Press, USA pp. $15-20$ 